\title{
The Rise and Fall of Somali Nationalism
}

\author{
Saeed Sheikh Mohamed
}

When the Somali state was formed in 1960 , most African countries envied the homogeneity of the Somali people. Unlike the African countries south of the Sahara, Somalis share the same culture and language; they believe in the same religion and belong to the same ethnic group. This is the only perspective from which European scholars and African writers base their analysis of Somali studies. However, they fail to observe the diversity of the same culture, which is an inherent characteristic of the clan system.

Despite their common characteristics, Somalis did not experience a centralized form of administration before the Europeans arrived, nor did they enjoy a statehood that encompassed all of the Somali tribes. Instead, they were organized in tribes, subtribes, clans, subclans and extended families. They had a traditional leadership that was responsible for the welfare and security of its followers, who lived on their own agricultural and grazing land.

When the Europeans arrived in Somalia, they did not respect the territorial integrity of the different tribes and just drew arbitrary boundaries on the map to mark their zone of influence. Consequently, the Somali territory was divided into five parts: the British Somaliland Protectorate, the Italian Somaliland, the French Somali Coast, the Northern Frontier District of Kenya (as part of the British East African Administration). The rest of the Somali territory (known as Western Somaliland or Ogaden) was left under the rule of King Melenik of Ethiopia.

The Europeans imposed new political structures on the Somali people, but they did not succeed in dismantling the tribal organizations. The superimposed colonial system subjugated the traditional structure and values, so the power base of the traditional authority was reduced. The country was divided into regions, districts, subdistricts and villages; men of the same tribe were found in different jurisdictions and sometimes under different colonial rule. The security and justice systems came under the colonial authorities. Hence, each tribe faced a new challenge in protecting its interest within the system, since its tribal organization and cultural values were in jeopardy. The traditional leaders had no option other than to submit themselves to the colonial administration. The only function left for them was to enforce solidarity among their followers in case of calamity or war and to try to defend their economic interests. However, the European dictatorship in rural areas. He also exacerbated hostility among the different Somali tribes, using divideand-rule tactics. Unfortunately, he betrayed his position of great trust by alienating the Somali tribes living in the North, particularly the Isaaqs, whose firm support was essential in combat. He diverted the purpose of his struggle to settle an old account with the Isaaqs. The Isaaqs retaliated after they organized themselves. The British took advantage of the situation and provided arms and ammunition to the Isaaqs. Although Mohamed Abdille Hassan was defeated in 1920,3 the war had disastrous consequences for the Somali people. Touval $(1963,54)^{4}$ confirms that the civil war Mohamed Abdille Hassan started claimed about onethird of the male population of the North. The end of Mohamed Abdille Hassan's tyranny presence on Somali soil and the alien administrative system was widely regarded as a threat to the very existence of the Somali people.

\section{The Mullah and His Revolt}

In 1898, at the beginning of the European colonization in Somalia, Mohamed Abdille Hassan, from Ogaden, challenged the colonial rule. ${ }^{1}$ He advocated waging a holy war against the European infidels and called for the unity of the Somali nation. He reawakened Somali nationalism, which was dormant because of tribal divisions. The Somali tribes in the North willingly accepted him as their unopposed leader and gave him full support in order to restore their territorial integrity and independence, although there was old hostility between his tribe and the other tribes in the North.

He waged a war against the British that continued from $1900-20{ }^{2}$ However, he lost the war after he established a closed a chapter of Somali nationalism. As a result, Somali unification was widely disregarded by the population of the North for more than two decades.

\section{The Resurgence of Somali Nationalism}

In 1941 the British military administration was established in the South, following the British victory over the Italians in the Horn of Africa. ${ }^{5}$ The Somali Youth League (SYL), the first political party in the South, was established in Muqdishoin 1946. TheSYL's agenda was to struggle for independence and unification of all the Somali territories. The idea was in line with the British policy at that time. All Somali territories, except French Somaliland, were under British control. The British were very keen on the strategic position of Somalia. Ernest Bevin, whowas the British foreign secretary at the time, was an ardent supporter of Somali unification and he 
confirmed the British government's commitment to maintaining the unity of the Somali people and territories.

The people of the British Somaliland Protectorate were generally enthusiastic about unity. However, the traditional authorities in the North accepted theidea with reservation because of what they experienced during the tyranny of Mohamed Abdille Hassan some thirty years before. The Somali National Society, the only political party in the North, which was established in $1935{ }^{6}{ }^{6}$ mobilized the masses and collaborated with the SYL leadership to preserve the unity of the Somali people. When the British government took the Somali case to the Security Council of the United Nations for settlement, the four powers (the United States, British, France and the Soviet Union) failed to agree on the destiny of the ex-Italian Somaliland. The issue was transferred to the United Nations General Assembly, which voted to leave the Somali case as it was before the war. ${ }^{7}$

It gave the Italian government the mandate to control the South as a United Nations trusteeship and to prepare the region for independence for ten years, which ended on July 1, 1960. The shortlived political union of the Somali people and territories collapsed by virtue of the United Nations General Assembly's resolution.

\section{The Peak of Somali Nationalism}

After the British government failed to control all the Somali territories, it entered into a secret deal with Haile Selassie to cede an important region of the northern nomads' dwelling to Ethiopia. The agreement became effective in November 1954 and the region known as the Haud and Reserved Area was annexed by the Ethiopian government. $^{8}$ The people of British Somaliland felt betrayed by the British authorities because the region was an important part of the traditional grazing land of the Protectorate.

This new development effected a complete turn around of political awareness in Somaliland. Somali nationalism was revived throughout the territories, particularly the North. The Somali people realized the weaknesses of the tribal system. They gave their primary loyalty to the political leaders instead of to their traditional leaders. The North was convinced that the only way to retrieve the Haud and Reserved Area was to join forces with the South and develop common goals and strategies based on the Somali people's hope for independence and unification. The political elite in the North, who were organized as the Somali National Society, laterbecame theSomaliNational League (SNL). ${ }^{9}$ They opted to unite with the South in order to form a strong government that could negotiate with the different European colonizers and the Ethiopian government for the liberation and the unification of all Somali territories.

\section{The Formation of the Somali State}

In the North, the new political elite benefited from Western education; they were devoted to Somali nationalism based on unity and brotherhood. They suppressed traditional leadership and values and advocated creating a strong central government based on democratically-elected political representation. Unfortunately, their nationalistic views were not based on sound political judgement. They could not foresee the government's role and the type of institutions needed to preserve checks and balances in the system, nor did they think of ways to protect the interests of their region after unification with the South, let alone power-sharing and regional representation in the central government.

The South was politically prepared for independence and already had a council of ministers and chamber of deputies. These gave the region experience in real politics and power profiteering. The political elite in the South, struggling for power, was divided on tribal lines and was not enthusiastic to unite with the North because they were notready to share government privileges at any cost. By contrast, the political leaders of the North, who were not fully aware of the political situation in the
South, wanted to forge the basis of Somali unity.

Some preliminary discussions took place in April 1960 between the authorities of the two regions. ${ }^{10}$ The political leaders in the South were very sceptical of the union, were not cooperative and wanted to abort the unification procedure by insisting on their own terms:

- That unification of the two regions must not require power-sharing.

- That the two regions must be fully integrated with a central administration system.

- That the capital must be Muqdisho, the capital city of the South.

Immediately afterindependenceon June 26,1960 , the political leadership of the North went to Muqdisho and signed the protocol of unification five days later on July 1 . The protocol was in accordance with the terms of the South. Northern politicians sacrificed their political ambition and regional interests for the sake of national unity because there was a great surge of patriotic feeling in the North.

Although the two regions were united, the legal process was not respected. The protocol of unification was not ratified by the two chambers of deputies in the North and the South separately as normal constitutional procedures stipulated, nor has there been a referendum on unification since then. The two chambers of deputies were merged. Adem Abdalle Osman was elected from the South as the first president of the new state and a central government was formed immediately. Hence, the government of Muqdisho ruled the North without any legal grounds for doing so. Once the chamber of deputies in the North became an integral part of the Somali parliament, there was no institution left in the North to represent the region. The thirty-three deputies from the North became a minority in the Somali Parliament, which included ninety deputies from the South. Regional parliamentary representation was not abased on a population census, but was individually determined by the two colonial authorities and the issue was never reviewed to rectify this. 


\section{Southern Domination}

When the State of Somalia was established, the North was better educated and its economy was better organized with a well balanced budget that was capable of generating some surplus, while the budget of the South was experiencing chronic deficit. ${ }^{11}$ However, the North was largely underrepresented in the first government of the new state. Out of fourteen ministers, only four with minor portfolios were from the North: the deputy prime minister with no specific responsibilities, the minister of defence, the minister of education and the deputy minister of agriculture. All the key positions were filled by men from the South. The key positions of government institutions, including military and police forces, were also dominated by southerners. ${ }^{12}$

In short, the executive and legislative bodies, along with other important institutions, were dominated by the South. This was in line with the policy formulated by the political leadership of the South who wanted to exclude the North from decision making. The political elite in the South did not consider the fragility of national unity, which wasinjeopardy. Frustrated young military officers in the North attempted a military coup in 1961 in an attempt to break away from the South. Although the coup was soon aborted, it was widely condoned by northeners who were deeply frustrated by southern domination.

\section{The Policy of Regionalism}

The policy of civilian governments from 1960 to 1969 lacked a broader vision to cope with national issues. Political leaders in the South were very shortsighted and envious of the economic development in the North, as compared to that in the South. They gambled with regional issues and committed themselves to dismantling the few institutions devised by the British to serve the interests of the people in the North. The Somali government downgraded the education system, health care, the media, etc. and did not provide sufficient funds to sustain these systems in the North, let alone undertake a development program in the region. At the same time, large-scale development projects implemented in the South contributed less than 20 percent in government revenue. Moreover, the North was deprived of its share of international development aid because 95 percent of the bilateral and multilateral aid were spent in the South. After more than thirty years of independence, the government has not established anything in the North that is worth mentioning. Furthermore, the political system in the country was in $1971 .^{13}$ However, he followed the policy established by his predecessors with regard to regional and tribal issues. He went too far in obliterating the economic base of the North in the name of socialism. He nationalized business, agriculture and the international trade. This had a tremendous impact on the national economy, particularly in the North, where peoplewere entrepreneurs par excellence. However, the Ogaden war in 1977 was a turning point when the Somali government wrongfully waged a war against Ethiopia over the Ogaden instead of looking for a political solution. As a result, the nation's meagre economic resources were diverted for military

\section{When the State of Somalia was established, the North was better educated and its economy was better organized with a well balanced budget that was capable of generating some surplus, while the budget of the South was experiencing chronic deficit. However, the North was largely underrepresented in the first}

government of the new state.

geared to create regionalism-North versus South-and tribal conflict throughout the country. Regional and tribal antagonism persisted until President Abdirashid Ali Sharmake was assassinated, which opened the door for a military rule.

\section{The Military Rule}

When Siad Barre came to power in a military coup on October 21, 1969, he immediately transformed the country, with help from the Soviets, from a state of anarchy to a personal rule. Institutions were created for espionage and counterespionage, and special courts were formed for so-called subversive actions and political crimes that were considered antirevolutionary. A wife was recruited to spy on her husband and a son was appointed to report on the family's activities. This system destroyed the family unit and social values, and trustbecamea rare commodity. This new and efficient political system allowed Siad Barre to rule Somalia by will, particularly after he embraced socialism purposes. Moreover,Siad Barredeclared the North as a war zone and the military governor in the North was ordered to confiscate private properties in the region for the war effort.

By the end of the war in 1978, Somalia was hosting 1.5 million refugees from Ethiopia, 750,000 of whom were from Ogaden, and the national economy was not in good shape. ${ }^{14}$ Living standards deteriorated and government services and institutions collapsed because of a lack of funds. The recession was severe and inflation was out of control. Consequently, corruption was rampant among civilians and the military in power. There was misuse of government funds and appropriation of private properties to supplement incomes.

In April 1978 some army officers attempted a coup. ${ }^{15}$ Although the coup was foiled, it exposed the oppressive nature of the Siad Barre's regime as Hassan $(1984,5)$ noted. ${ }^{16}$ Siad Barre ruled Somalia with an iron fist. Injustice, intimidation, mass arrests, summary executions and lawlessness became hallmarks of the regime. This incited 
mass discontent. A group of military and civilian dissidents founded the Somali Democratic Action Front (SODAF) in 1978, the first resistance movement to challenge the system. ${ }^{17}$ As the key leaders of the front were from the eastern regions of Somalia, the military government waged a war against the civilians in that area. Thousands of defenceless civilians lost their lives in a scorched-earth policy. Although the SODAF (later known as the Somali Salvation Democratic Front) was well organized and well equipped, it failed to sufficiently mobilize the masses in order to get a broad popular base.

In April 1981 there was a renewed effort to create a strong opposition. A group of intellectuals and former senior civil servants, who were mainly from the North, formed the Somali National Movement (SNM). The SNM's main objective was to restore democracy in the country. As soon as the SNM was launched, a military command was formed for ethnic cleansing. It was known as the Dabar Goynta Isaaqa (the Isaaq Exterminators) ${ }^{18}$ The northern Isaaq clans were deprived of their legal, economic and social rights. By late 1981, hundreds of prominent Isaaqs were detained, private properties were confiscated and businesses were looted and closed. The policy of economic destabilization in the region was openly adopted by the military governor at the time, General Mohamed Hashi Ghani, a relative of General Siad Barre. ${ }^{19}$

The military command in the North occupied the region by force and committed atrocities towards innocent civilians. According to Lewis $(1990,58)$ in 1985 the North was like a colony under oppressive foreign control. ${ }^{20}$ The Isaaqs' animosity towards military forces forced them to side with the opposition. The SNM tookadvantage of the situation and succeeded in getting total support from the Isaaqs and substantial popularity in the South. Siad Barre, who prolonged his rule by pitting different tribes against each other, used the military to end the conflict. The government's hostility towards the Isaaqs intensified in 1988 when the SNM defeated the military in the North and captured Hargeisa, the capital city of the North. Siad Barre ordered war against the Isaaqs and used the military to destroy their homeland. Moreover, the Ogaden refugees were encouraged to fight against the Isaaqs and to take their properties and homes in order to cleanse them from their homeland. In 1988 over 50,000 civilians were killed in Hargeisa, and Hargeisa and Burao were reduced to rubble. ${ }^{21}$ Survivors escaped to the rural areas, but the government troops, including the air force, turned on these defenceless and innocent civilians. Consequently, more than 300,000 people took refuge in Ethiopia, while over a million refugees were uprooted from their dwellings and scattered in the countryside. This mass destruction wasthe final episode in thirty

\section{The Somali people urgently need a political solution to ease their plight, but any foreign military intervention may escalate hostilities.}

years of political failure of Somalia's southern-based leadership.

Siad Barre's power base was exclusively derived from his clan Mareehaan, but he received tactical and intermittent support from the different clans of the Darood tribe, of which Mareehaan was one. The government tightened its grip on the capital. The Hawiye clans around Muqdisho, together with some other small tribes, took up arms against the military government.

The SNM, which failed to recruit all the opposition groups, realized that it could not depose Siad Barre without the assistance of other main tribes. The SNM entered a military agreement with the United Somali Congress (USC), an opposition movement formed in January 1989 by dissidents of the Hawiye tribe, and the Somali Patriotic Movement (SPM), a small group from the Ogaden clan. Siad Barre, as usual, used his Darood clans against the opposition coalition in order to protect his regime, but this time it was too late because the militants were fighting in his courtyard. The presence of the Hawiye-dominated USC in the opposition alliance was an important factor in ending the military dictatorship. Siad Barre was defeated on January 27, 1991, but his legacy included long-lasting hostilities among the Somali tribes, particularly those in the South. Moreover, the defeat of the military government and the weak organization of the opposition movement created a power vacuum in Muqdisho. Once Siad Barre was ousted, a power struggle started among the USC leaders. As a result, the undisciplined USC freedom fighters started to take their revenge on the Darood clans and confiscated their properties. A USC faction based in Muqdisho unilaterally appointed Ali Mahdi Mohamed as head of state and formed a government without the consent of the USC military wing and the other two liberation movements, the SNM and the SPM. Immediately afterward, two factions of the USC confronted each other with arms. ${ }^{22}$

The SNM, frustrated with the chaos in Muqdisho, yielded to pressure from the masses in the North, who opted to form an independent state in the region. ${ }^{23}$ As soon as the North seceded, the war escalated in Muqdisho between the two USC factions, led by Ali Mohdi Mohamed, the interim president, and the popular Mohamed Farah Aideed, the secretary general of the USC, to determine by force whose authority should prevail in the capital. However, the combat is no longer about political or ideological differences but about simple interclan conflict. As a result, the South has fallen into anarchy and all government institutions in Muqdisho have collapsed. Consequently, individual tribes have proclaimed their independence from Muqdisho.

The catastrophic situation in Somali urgently requires a political solution to ease the people's plight, but any foreign military intervention may escalate hostilities. However, the international community has a significant and positive role to play in current Somali affairs by encouraging the handling of politics according to Somali traditions. 圆 